DOI: https: / / doi.org/10.53754/iscs.v1i1.8

\title{
IMPLEMENTASI PENGEMBANGAN KEMAMPUAN MENGENAL HURUF SELAMA MASA BELAJAR DI RUMAH PADA ANAK
}

\section{IMPLEMENTATION OF THE DEVELOPMENT OF LETTER RECOGNITION ABILITY DURING THE HOME STUDY TIME IN CHILDREN}

\author{
Hikmatul Husna \\ Universitas Negeri Yogyakarta \\ Email; hikmatul.husna@student.uny.ac.id
}

\begin{abstract}
This study describes the implementation of language learning in children aged 4-5 years in TK ABA JOGOKARYAN while studying at home. The assessed research was to describe the implementation of letter recognition in children aged 4-5 years at TK ABA Jogokaryan. This research is a qualitative approach and descriptive research type. The subjects of this study were the principal, class $A$ teachers, parents of class $A$ students, and grade A children. The object of this study was the implementation of letter recognition in children aged 4-5 years at TK ABA JOGOKARYAN in class A2 while studying at home. The data collection techniques used were interviews and documentation. The data analysis technique uses the theory of Miles and Huberman, namely data collection, data condensation, data presentation, and concluding. The validity of the research data was re-tested using source triangulation and method triangulation. The results of this study indicate: 1) Planning begins with making daily lesson plans, then sent to parents via Whatsapp group or give to parents directly when they come to school. 2) The implementation of letter recognition is played by parents by accompanying and documenting the learning activity process. 3) Evaluation is carried out through documentation reported by parents on the Whatsapp group. 4) Supporting factors include guidance from parents in letter recognition while children are studying at home, online media, which is used as a communication tool for teachers and parents, and special programs on television that help children's learning while at home. At the same time, the inhibiting factors are some families who do not make it a habit knowing letters, parents' busyness, mood swings, and a lack of enthusiasm for learning.
\end{abstract}

Keywords: language learning, letter recognition, study at home.

\section{PENDAHULUAN}

Undang-undang Nomor 20 Tahun 2003 Pasal 1 Ayat 14 tentang Sistem Pendidikan Nasional menyatakan bahwa Pendidikan Anak Usia Dini (PAUD) adalah suatu upaya pembinaan yang ditujukan kepada anak sejak lahir sampai dengan usia enam tahun yang dilakukan melalui pemberian rangsangan pendidikan untuk membantu pertumbuhan dan perkembangan jasmani dan rohani agar anak memiliki kesiapan dalam memasuki pendidikan lebih lanjut (RI, 2003). (Adhe, 2016) dalam sebuah artikelnya dengan mengutip Sujiono, ia menambahkan bahwa pendidikan bagi anak usia dini merupakan upaya untuk menstimulasi, membimbing, mengasuh dan memberikan kegiatan yang dapat menghasilkan kemampuan dan keterampilan pada anak.

Dewasa ini, berbagai fenomena tentang pembelajaran pengembangan bahasa, (E B, 1972) berpendapat dengan penggunaan metode dalam pembelajaran membantu anak dalam mencapai tujuan pembelajaran yang akan dicapai, namun hal tersebut membutuhkan waktu lebih banyak dan persiapan pembelajaran yang bervariasi dan menarik untuk anak. (Dhieni, 2008) mengungkapkan perkembangan bahasa anak adalah sebagai salah satu dari kemampuan dasar yang harus dimiliki anak-anak, terdiri dari 
perkembangan bicara, perkembangan menulis, perkembangan membaca, dan perkembangan menyimak.

Melihat fenomena dan kenyataan seperti yang telah dipaparkan di atas, tentunya penting untuk mengenalkan huruf sejak dini yang bertujuan untuk membantu terbina dan terbentuknya pemahaman huruf. Pendidikan bahasa pada Pendidikan Anak Usia Dini (PAUD) merupakan fondasi yang kokoh dan sangat penting keberadaannya. Jika hal tersebut telah tertanam dengan baik pada anak usia dini, hal tersebut merupakan awal yang baik bagi pendidikan anak untuk melanjutkan pendidikan ke jenjang selanjutnya.

Adapun pendidikan bahasa yang diberikan pada masa usia dini berdasarkan Peraturan Menteri Pendidikan dan Kebudayaan Nomor 137 Tahun 2014 tentang Standar Nasional PAUD diuraikan bahwa tingkat perkembangan bahasa pada Kelompok A (4-5 tahun) antara lain adalah dapat Mengenal simbol-simbol, membuat coretan yang bermakna, meniru (menuliskan dan mengucapkan) huruf A-Z. Tingkat pencapaian perkembangan pengenalan huruf pada anak usia 4-5 tahun yaitu mengenal simbol-simbol, membuat coretan yang bermakna, meniru (menuliskan dan mengucapkan) huruf A-Z (RI, 2014).

Sejak bulan Maret 2020 World Health Organization (WHO) resmi mengumumkan bahwa wabah Coronavirus Disease (Covid-19) sebagai pandemi global (Kompas, 2020). Kebijakan yang diambil oleh pemerintah Republik Indonesia melalui Peraturan Pemerintah Republik Indonesia Nomor 21 Tahun 2020 tentang Pembatasan Sosial Berskala Besar (PSBB) dalam rangka percepatan penanganan Covid-19 yang berlaku di berbagai sektor yakni pendidikan, ekonomi, keagamaan, sosial, dan kegiatan masyarakat lainnya.

Berdasarkan hasil wawancara pada salah satu guru lembaga PAUD, tidak semua orang tua aktif terlibat dalam proses pembelajaran daring. Hal tersebut dikarenakan masih terdapat orang tua peserta didik yang gagap teknologi dan merasa kurang peduli dalam pelaksanaan program belajar di rumah, sehingga guru tidak dapat memantau perkembangan peserta didik dan mempersulit guru dalam proses penilaian hasil belajar anak. Meskipun demikian, guru tetap dituntut kreativitas dalam menstimulasi perkembangan anak melalui Lembaga PAUD masing-masing.

TK $A B A$ Jogokaryan merupakan lembaga Pendidikan Anak Usia Dini bernuansa islami dan agamis yang berlokasi di Jogokaryan MJ III No. 487, Mantrijeron, Yogyakarta. TK ABA Jogokaryan merupakan lembaga PAUD yang banyak diminati oleh masyarakat karena merupakan lembaga yang mengedepankan pendidikan nilai-nilai agama dan moral sejak dini. Salah satu program unggulan dari TK ABA Jogokaryan adalah mencetak generasi Qurani yang beriman dan bertakwa, apabila anak lulus dari TK ABA Jogokaryan maka anak sudah melek dengan baca tulis Alquran. Adapun kegiatan-kegiatan pengenalan huruf yang diterapkan pada peserta didik di TK ABA Jogokaryan di antaranya seperti bermain yang berkaitan dengan huruf menggunakan berbagai media, permainan outdoor dan indoor tentang pengenalan huruf, dan masih banyak lagi. Ditambahkan, hasil wawancara dengan Kepala Sekolah TK ABA Jogokaryan yang dilakukan pada 7 Desember 
2020, pada masa pandemi Covid-19 ini TK ABA Jogokaryan merupakan salah satu lembaga PAUD yang tetap berkomitmen mengenalkan huruf pada anak selama anak belajar di rumah. Namun sampai saat ini belum ada kajian mendalam terkait implementasi pembelajaran nilai agama dan moral selama anak belajar di rumah. Hal tersebut membuat peneliti tertarik untuk mengkaji lebih dalam mengenai implementasi pembelajaran mengenal huruf khususnya pada anak usia 4-5 tahun selama belajar di rumah, sehingga penelitian ini memiliki urgensi yang signifikan. Penelitian terkait pengembangan pengenalan huruf juga belum banyak dilakukan oleh peneliti lain. Pemilihan lokasi penelitian di TK ABA Jogokaryan didasarkan pada asumsi sekolah tersebut memiliki nilai unggul di bidang APE.

Fokus masalah dalam penelitian ini yaitu TK ABA Jogokaryan merupakan salah satu lembaga PAUD yang tetap berkomitmen mengenalkan huruf selama anak belajar di rumah. Namun sampai saat ini belum ada kajian mendalam terkait implementasi pengenalan huruf selama anak belajar di rumah. Adapun tujuan penelitian ini adalah untuk mendeskripsikan implementasi pengenalan huruf pada anak usia 4-5 tahun di TK ABA Jogokaryan.

Secara teoritis, penelitian ini diharapkan dapat menambah informasi mengenai teori implementasi pengenalan huruf pada anak usia dini yang meliputi perencanaan, kegiatan, dan penilaian hasil belajar keaksaraan. Kemudian secara pragmatis, penelitian ini diharapkan memberi signifikansi kepada peneliti lain yang masih relevan dengan topik pembahasan, guru, dan sekolah penyelenggara pendidikan AUD.

Gu (2015) mengungkap kemampuan mengenal huruf adalah tahap perkembangan anak dari belum tahu menjadi tahu tentang keterkaitan bentuk dan bunyi huruf, sehingga anak dapat mengetahui bentuk huruf dan memaknainya. Mengenal huruf dalam bahasa asing seperti bahasa Arab dapat dilalui dengan metode dikte atau imla' (Susanti, 2020). Dalam pembelajarannya dapat dilalui dengan berbagai metode dan media pembelajaran, agar keterampilan berbahasa berkembang secara optimal (Maghfiroh et al., 2021). Mengenalkan huruf pada anak adalah olah kognitif dasar. Pengenalan ini dapat diproyeksikan dengan keterampilan mendengar terlebih dahulu sebelum guru berlanjut pada keterampilan berikutnya (Mukminin, 2020). Mengungkap kemampuan mengenal huruf pada AUD sebagaimana lazimnya pengenalan kecerdasan yang lain pada AUD harus diimbangi dengan dua hal, yaitu belajar dan bermain. Hal ini dikarenakan bahwa usia AUD merupakan usia primer untuk belajar dengan bermain (Wahyuni \& Azizah, 2020).

Lebih lanjut, belajar mengenal huruf menurut (Gu, 2015) merupakan komponen hakiki dari perkembangan baca tulis. Anak perlu mengetahui atau mengenal dan memahami huruf abjad untuk akhirnya menjadi pembaca dan penulis yang mandiri dan lancar (Hanum, 2016). (Elizabeth, 1978) menjelaskan bahwa belajar huruf adalah tonggak kurikulum Taman Kanak-kanak lewat penyingkapan berulang dan bermakna kepada peristiwa-peristiwa baca tulis, sehingga anak menjadi tahu akan huruf-huruf dan 
mengerti bahwa huruf-huruf membentuk sebuah kata. (E B, 1972) mengungkapkan bahwa dengan strategi pengenalan huruf sejak usia dini sangat bermanfaat bagi perkembangan bahasa anak, karena membantu mempersiapkan anak untuk dapat membaca dengan mudah. (E B, 1978) menambahkan bahwa anak yang dapat mengenal huruf dengan baik cenderung memiliki kemampuan membaca dengan lebih baik. Pengenalan huruf tidak lepas dari oposisi bahasa strukturalisme, di mana pemerolehan bahasa kedua adalah dominasi perkembangan atas akuisisi bahasa pertama (Putra, 2017).

\section{METODE}

Penelitian ini menggunakan pendekatan kualitatif (Moeloeng, 2011). Penelitian ini dilakukan secara kolaboratif antara guru kelas dan peneliti. Guru kelas sebagai pengajar selama pembelajaran jarak jauh dan mahasiswa sebagai peneliti. Kolaborasi diwujudkan untuk mendapatkan data yang akan disajikan dan memperjelas hasil dari penelitian yang dikaji. Penelitian ini juga disebut dengan penelitian kolaboratif, di mana peneliti akan bekerja sama dengan guru pengajar di lokasi penelitian.

Penelitian mengenai implementasi pengenalan huruf selama anak belajar di rumah dilaksanakan di TK ABA Jogokaryan yang berlokasi di Jogokaryan MJ III No. 487, Mantrijeron, Yogyakarta. Penelitian dilakukan pada bulan Maret hingga Juni 2020. Diawali dengan pra observasi, kemudian observasi lanjutan dan penelitian di TK ABA Jogokaryan. Sekolah ini dipilih sebagai tempat penelitian dikarenakan: (1) sekolah menerapkan kegiatan pengenalan huruf bagi peserta didik selama anak belajar di rumah; (2) pengenalan huruf menjadi salah satu yang penting ditanamankan oleh lembaga sekolah. Fokus penelitian ini adalah implementasi pengenalan huruf pada anak usia 4-5 tahun atau kelompok kelas A2 selama anak belajar di rumah.

Data primer dalam penelitian ini adalah Kepala Sekolah, Guru kelas A3, dan orang tua kelas A2. Sedangkan data sekundernya adalah buku-buku atau dokumentasi yang berhubungan dengan penelitian ini. Adanya data primer dan sekunder sangat penting sebagai penjelasan asal data penelitian diperoleh (Dimyati, 2020)

Teknik pengumpulan data dalam penelitian ini adalah wawancara dan dokumentasi. Wawancara dilakukan untuk mendapatkan data mengenai implementasi pengenalan huruf pada anak usia 4-5 tahun di TK ABA Jogokaryan selama anak belajar di rumah. Sedangkan dokumentasi dilakukan dengan mengambil serta melihat dokumen yang ada di TK ABA Jogokaryan. Selain itu, peneliti juga akan merekam atau memotret terkait implementasi pengenalan huruf di TK ABA Jogokaryan.

Adapun instrumen yang digunakan dalam penelitian ini di antaranya: (1) pedoman Wawancara; (2) pedoman Dokumentasi, yakni dengan membandingkan hasil wawancara dengan dokumentasi.

Keabsahan data penelitian ini dengan menggunakan metode triangulasi (Sugiyono, 2006), yaitu: (1) triangulasi Sumber, dilakukan untuk mengecek kredibilitas data yang 
diperoleh melalui sumber data yakni kepala sekolah, guru kelas A2, dan orang tua; (2) triangulasi Metode.

Analisis data yang digunakan dalam penelitian ini yaitu teknik analisis model interaktif Miles dan Huberman dalam (Denzin, 2009). Data-data yang telah terkumpul dalam penelitian ini dianalisis dengan menggunakan data kualitatif deskriptif yang sifatnya pemaknaan dalam mengungkapkan keadaan atau karakteristik sumber data. Analisis data yang digunakan dalam penelitian ini yaitu teknik analisis model interaktif Miles dan Huberman. Aktivitas dalam analisis data kualitatif dilakukan secara terus menerus hingga tuntas, sehingga datanya sudah jenuh. Adapun langkah-langkah yang ditempuh di antaranya: (1) pengumpulan data; (2) kondensasi data; (3) penyajian data; dan (4) verifikasi data.

\section{PEMBAHASAN}

Hasil penelitian implementasi pengenalan huruf selama masa belajar di rumah pada anak kelompok A2 TK ABA Jogokaryan diklasifikasikan ke dalam empat langkah, di antaranya: (1) perencanaan; (2) pelaksanaan; (3) evaluasi; dan (4) penjelasan faktor penghambat dan pendukung kegiatan. Adapun penjelasannya sebagai berikut:

\section{Perencanaan}

Perencanaan implementasi pengenalan huruf di TK ABA Jogokaryan disesuaikan dengan RPPH yang telah dibuat oleh guru sebelumnya. Adapun materi bahasa yang diajarkan kepada anak seperti membentuk bentuk huruf dari berbagai media, menebalkan huruf, bermain dengan balok huruf, bermain domino huruf, bermain dengan kartu huruf, mewarnai bentuk huruf yang ada di majalah, dan masih banyak lagi. Dalam implementasi pengenalan huruf dilakukan dengan menggunakan metode yang bervariasi. Selama pandemi Covid-19 yang menjadikan anak belajar di rumah, perencanaan pengenalan huruf tidak lagi sesuai dengan RPPH yang telah dibuat, akan tetapi materi pembelajaran diserahkan kepada guru kelas masing-masing. Adapun materi pengenalan huruf yang diberikan selama anak belajar di rumah yaitu menuliskan nama sendiri dengan dibantu orang tua, menyebutkan huruf, menebalkan huruf-huruf dengan bantuan orang tua, menyusun kata dengan kartu huruf, bermain dengan balok huruf atau barang yang tersedia di rumah, membentuk bentuk huruf dari plastisin, menempel biji-bijian mengikuti bentuk huruf yang sudah ditulis oleh orang tua, serta mewarnai gambar huruf yang ada di majalah.

\section{Pelaksanaan}

Implementasi pengenalan huruf dilakukan setiap hari saat kegiatan inti. Akan tetapi, selama anak belajar di rumah pelaksanaan pengenalan huruf diserahkan kepada orang tua anak. Guru dan orang tua memiliki WhatsApp group yang digunakan untuk media berkomunikasi. Pemberian tugas harian dikirimkan oleh guru melalui WhatsApp group 
atau memberikan langsung kepada orang tua ketika orang tua datang ke sekolah guna mengambil majalah-majalah dan menyelesaikan administrasi sekolah. Adapun materi pengenalan huruf yang diberikan oleh guru selama anak belajar di rumah antara lain menuliskan nama sendiri dengan dibantu orang tua, menyebutkan huruf, menebalkan huruf-huruf dengan bantuan orang tua, menyusun kata dengan kartu huruf, bermain dengan balok huruf atau barang yang tersedia di rumah, membentuk bentuk huruf dari plastisin, menempel biji-bijian mengikuti bentuk huruf yang sudah ditulis oleh orang tua, serta mewarnai gambar huruf yang ada di majalah. Dokumentasi hasil dari kegiatan belajar anak dikirimkan oleh orang tua kepada guru melalui Whatsapp group dalam bentuk foto maupun video.

\section{Evaluasi}

Evaluasi pengenalan huruf di TK ABA Jogokaryan dilakukan setiap hari menggunakan teknik penilaian catatan anekdot, percakapan, penugasan, dan hasil karya. Hasil penilaian harian direkapitulasi ke dalam format penilaian mingguan yang kemudian ditulis dalam rapor anak yang dilaporkan setiap semester. Akan tetapi, dengan adanya wabah Covid-19 mengubah penilaian guru yang hanya berdasarkan dokumentasi hasil kegiatan belajar anak yang dikirimkan oleh orang tua kepada guru melalui Whatsapp group, misalnya hasil pengambilan gambar anak ketika menulis nama sendiri, menebalkan huruf, membentuk kata dari bombik, dan foto hasil karya lainnya.

\section{Faktor Pendukung, Penghambat, dan Kontribusinya}

Faktor pendukung pengenalan huruf dari rumah yaitu lingkungan keluarga yang menyadari akan pentingnya pengenalan huruf pada anak sejak usia dini dapat menerapkan kebiasaan baik yang diajarkan di sekolah selama anak di rumah, serta adanya media elektronik yang dapat mempermudah komunikasi orang tua dan guru dalam pengiriman tugas. Sedangkan faktor penghambat implementasi pengenalan huruf selama anak belajar di rumah yaitu lingkungan keluarga yang tidak mendukung pengenalan huruf pada anak, suasana hati anak yang mudah berubah dan tidak adanya teman sebaya seperti ketika belajar di sekolah sehingga semangat anak dalam belajar berkurang. Upaya yang dilakukan oleh guru yaitu meningkatkan komunikasi yang baik dan kerja sama dengan orang tua dalam mengenalkan huruf selama anak belajar di rumah.

\section{Analisis}

Perkembangan bahasa merupakan salah satu aspek perkembangan anak usia dini yang sangat penting bagi kelanjutan pendidikan di jenjang selanjutnya ( $\mathrm{Gu}, 2015)$. TK ABA Jogokaryan merupakan lembaga Pendidikan Anak Usia Dini yang menanamkan pengetahuan tentang huruf sejak usia dini yang tercantum dalam visi misi dan tujuan sekolah. Implementasi pengenalan huruf dilakukan mulai dari perencanaan, 
pelaksanaan, dan evaluasi. Hal ini sesuai dengan pendapat (Nasution, 2015) bahwa ada tiga tahapan dalam pelaksanaan pembelajaran, yaitu merencanakan pembelajaran, melaksanakan pembelajaran, dan mengevaluasi pembelajaran.

Berdasarkan hasil penelitian, TK ABA Jogokaryan telah melakukan perencanaan pengenalan huruf dengan merancang dan mempersiapkan segala sesuatu sebelum pelaksanaan pengenalan huruf berlangsung. Perencanaan pengenalan huruf sudah sesuai dengan pendapat (Hamalik, 2014), bahwa pembelajaran perlu direncanakan agar dalam pelaksanaan pembelajaran dapat berlangsung dengan baik dan dapat mencapai hasil sesuai dengan yang diharapkan.

Adanya wabah Covid-19 menyebabkan implementasi pengenalan huruf di TK ABA Jogokaryan mengalami perubahan dari sebelumnya berpusat pada guru dan peserta didik melalui kegiatan bermain sambil belajar kemudian beralih pada orang tua peserta didik. Hal ini sesuai dengan Surat Edaran Nomor 4 Tahun 2020 tentang Pelaksanaan Kebijakan Pendidikan dalam Masa Darurat Penyebaran Covid-19 yang salah satu isinya membuat proses kegiatan pembelajaran dilaksanakan di rumah dengan metode daring/ jarak jauh. Perubahan pola dan pelaksanaan pendidikan tersebut berdampak pada perencanaan, pelaksanaan dan evaluasi pengenalan huruf untuk peserta didik. Perencanaan pembelajaran tidak sesuai dengan RPPH yang telah dibuat sebelum adanya pandemi covid-19, akan tetapi guru menyusun RPPH yang baru disesuaikan dengan situasi dan kondisi sekarang. Namun RPPH yang dibuat selama pandemi Covid-19 belum sesuai dengan format RPPH yang baik dan benar karena hanya terdapat materi pembelajaran saja yang dikirimkan secara langsung kepada orang tua melalui Whatsapp group.

Pelaksanaan implementasi pengenalan huruf tidak terlepas dari peran orang tua dan guru dalam berkomunikasi dan menjamin kebutuhan dalam belajar anak terpenuhi, Hewi, L., Asnawati, L. (2020). Peran orang tua selama anak belajar di rumah menjadi peran utama. Orang tua sebagai tempat pertama yang mengetahui perkembangan anak menjadi kontrol dan guru anak selama di rumah. Hal ini berarti bahwa sebutan pendidik (guru) PAUD tidak hanya pada guru PAUD seperti biasa, akan tetapi ungkapan pendidik anak usia dini juga melekat pada orang tua atau ungkapan dalam pendidikan bahwa orang tua adalah pendidik pertama dan utama bagi anak yang sangat terasa pada masa Covid-19 ini. (Elizabeth, 1978) menjelaskan bahwa orang tua adalah inti dari perkembangan anak karena orang tualah yang paling sering interaksi, komunikasi, dan pemantauan aktivitas yang dilakukan oleh anak selama proses belajar dan bermainnya di rumah (Nuraeni, 2016).

Evaluasi implementasi pengenalan huruf selama masa pandemi dilaksanakan setiap minggunya. Karena tidak memungkinkan untuk dilaksanakan harian disebabkan orang tua belum tentu bisa mengirimkan hasil karya anak setiap harinya.

Dalam implementasi pengenalan huruf di TK ABA Jogokaryan selama anak belajar di rumah, terdapat beberapa faktor yang menjadi pendukung dan penghambat. 
Berdasarkan hasil wawancara, dapat diketahui bahwa faktor pendukung dalam implementasi pengenalan huruf selama anak belajar di rumah meliputi:

1. Adanya bimbingan dari orang tua dan keluarga dalam pengenalan huruf selama anak belajar dari rumah sehingga terjadi keseimbangan dengan pengenalan huruf di sekolah.

2. Adanya media daring yang dijadikan alat komunikasi oleh guru dan orang tua dalam pengenalan huruf selama anak belajar di rumah.

3. Adanya program khusus di televisi yang dapat digunakan untuk membantu belajar anak selama di rumah.

Sementara faktor penghambat dalam implementasi pengenalan huruf selama anak belajar di rumah yaitu:

1. Sebagian keluarga yang tidak membiasakan adanya pembelajaran huruf pada anak menjadikan anak tidak menerapkan ilmu yang sudah di dapatkan di sekolah.

2. Kesibukan orang tua, sehingga tidak bisa selalu mendampingi anak belajar.

3. Perubahan suasana hati anak dan kurangnya semangat belajar anak karena tidak ada teman.

Untuk mengatasi faktor penghambat dalam implementasi pengenalan huruf selama anak belajar di rumah, upaya yang dilakukan oleh guru yaitu meningkatkan komunikasi yang baik dan kerja sama dengan orang tua dalam pengenalan huruf selama anak belajar di rumah

\section{KESIMPULAN}

Pada anak usia 4-5 tahun di TK ABA Jogokaryan selama belajar di rumah di mulai dengan membuat materi pembelajaran mingguan yang kemudian di kirimkan kepada orang tua peserta didik melalui Whatsapp group atau memberikan kepada orang tua langsung ketika orang tua datang ke sekolah untuk mengambil majalah anak dan menyelesaikan administrasi.

Pelaksanaan pembelajaran pengenalan huruf pada anak usia 4-5 tahun di TK ABA Jogokaryan selama belajar di rumah diperankan oleh orang tua dan siswa di rumah masing-masing. Setelah orang tua menerima tugas mingguan dari guru, orang tua yang menjadi pendidik (guru) bagi anak, orang tua yang mendampingi anak dalam kegiatan pembelajaran dan mendokumentasikan proses kegiatan pembelajaran. Adapun materi terkait pembelajaran pengenalan huruf yang diberikan kepada anak selama belajar di rumah antara lain menuliskan nama sendiri dengan dibantu orang tua, menyebutkan huruf, menebalkan huruf-huruf dengan bantuan orang tua, menyusun kata dengan kartu huruf, bermain dengan balok huruf atau barang yang tersedia di rumah, membentuk bentuk huruf dari plastisin, menempel biji-bijian mengikuti bentuk huruf yang sudah ditulis oleh orang tua, serta mewarnai gambar huruf yang ada di majalah.

Evaluasi pembelajaran pengenalan huruf pada anak usia 4-5 tahun di TK ABA Jogokaryan selama belajar di rumah dilaksanakan melalui hasil dokumentasi rekaman 
kegiatan dan dokumentasi hasil kerja anak yang dilaporkan oleh orang tua kepada guru di Whatsapp group.

Penelitian ini mendeskripsikan faktor-faktor pendukung di antaranya adanya bimbingan dari orang tua dan keluarga dalam pengenalan huruf selama anak belajar dari rumah sehingga terjadi keseimbangan dengan pengenalan huruf di sekolah, adanya media daring yang dijadikan alat komunikasi oleh guru dan orang tua dalam pengenalan huruf selama anak belajar di rumah, serta adanya program khusus di televisi yang dapat digunakan untuk membantu belajar anak selama di rumah.

Adapun faktor penghambat dari implementasi pengenalan huruf selama belajar di rumah yaitu lingkungan keluarga yang tidak membiasakan mengenalkan huruf pada anak menjadikan anak tidak menerapkan ilmu yang sudah didapatkan di sekolah, kesibukan orang tua sehingga tidak bisa selalu mendampingi anak belajar, serta perubahan suasana hati anak dan kurangnya semangat belajar anak.

\section{DAFTAR PUSTAKA}

Adhe, K. R. (2016). Guru Pembentuk Anak Berkualitas. Jurnal CARE (Children Advisory Research and Education), 3(3), 42-51.

Denzin. (2009). Qualitative Research. Pustaka Pelajar.

Dhieni, N. (2008). Metode Pengembangan Bahasa. Pusat Penerbitan Universitas Terbuka.

Dimyati, j. (2020). Metodologi Penelitian Pendidikan \& Aplikasinya. Kencana.

E B, H. (1972). Child Development (5thed). McGraw-Hill Koyakusha.

E B, H. (1978). Child Development. McGraw-Hill Book Company.

Elizabeth, H. (1978). Developmental psychology (4thed). Tata McGrew-Hill Publishing Company.

Gu, L. (2015). Language ability of young English language learners: Definition, configuration, and implications. Language Testing, 32(1), https://doi.org/10.1177/0265532214542670

Hamalik, O. (2014). Administrasi dan Supervisi Pengembangan Kurikulum. Madani Maju. Hanum, J. (2016). Strategi Belajar Mengajar. Deepublish.

Kompas. (2020). Who umumkan virus corona sebagai pandemi global.

Maghfiroh, L., Setyowati, N., \& Suryani, T. Z. (2021). Al-Ibtikārāt fi Istikhdām Wasāil Ta'līmiyyah al-Lugah al-'Arabiyyah Litahsīn al-Mahārāt al-Lugawiyyah fi "Așri al-Wabā” Covid-2019. Aphorisme: Journal of Arabic Language, Literature, and Education, 2(1), 2332. https://doi.org/10.37680/aphorisme.v2i1.669

Moeloeng, L. (2011). Metodologi Penelitian Kualitatif. Rosda Karya.

Mukminin, A. (2020). Ta'līm Al-Lughah Al-'Arabiyyah baina Al-Ṭarīqah Al-Sam'iyyah AlSyafawiyyah wa Dūnihā li Ṭullāb Al-Ṣaf Al-S̄āmin bi Al-Madrasah Al-S̄ānawiyyah AlIslāmiyyah Al-Ma'ārif 1 Ponorogo. Aphorisme: Journal of Arabic Language, Literature, and Education, 1(2), 121-148. https://doi.org/10.37680/aphorisme.v1i2.475

Nasution. (2015). Asas-asas Kurikulum. Bumi Aksara. 
Received: 2021-02-09 Revised: 2021-03-14 Approved: 2021-03-14

Nuraeni. (2016). PERAN ORANG TUA DALAM PENGEMBANGAN LITERASI DINI ANAK KELOMPOK B DI GUGUS 7 MANGUNAN KECAMATAN DLINGO BANTUL.

Putra, W. H. (2017). Strukturalisme dan Revitalisasi Applied Linguistics. Proceedings of Annual Conference for Muslim Scholars, Seri 2, 868-877.

RI, K. (2003). Undang-undang RI Nomor 20 Tahun 2003 pasal 1 angka 14 tentang Sistem Pendidikan Nasional.

RI, K. (2014). Peraturan Menteri Pendidikan dan Kebudayaan Nomor 137 Tahun 2014 tentang Standar Nasional PAUD.

Sugiyono. (2006). Metode Penelitian Pendidikan. Alfabeta.

Susanti, S. (2020). Efektivitas Metode Imla' Manzur dalam Meningkatkan Keterampilan Menulis Bahasa Arab Siswa Madrasah Tsanawiyah. Aphorisme: Journal of Arabic Language, Literature, and Education, 1(2), https://doi.org/10.37680/aphorisme.v1i2.439

Wahyuni, F., \& Azizah, S. M. (2020). Bermain dan Belajar pada Anak Usia Dini. Al-Adabiya: Jurnal Kebudayaan Dan Keagamaan, 15(01), 161-179. https://doi.org/10.37680/adabiya.v15i01.257

\section{Copyright (c) 2021 Hikmatul Husna}

cc (7) \& This work is licensed under a Creative Commons Attribution-NonCommercial 4.0 International License. 